\title{
Analisis Sistem Informasi Akuntansi Penerimaan dan Pengeluaran Kas Terhadap Sistem Pengendalian Internal Kas Pada PT. Bulan Biru Tour and Travel
}

\author{
Dinda Kama Dita, Tantina Haryati \\ Prodi Akuntansi Fakultas Ekonomi dan Bisnis \\ Universitas Pembangunan Nasional "Veteran” Jawa Timur \\ dindakamaa@gmail.com, tantinah.ak@upnjatim.ac.id
}

\begin{abstract}
A company needs an internal control system because to maintain the existence of cash appropriately for managing and controlling cash, one of which is cash receipts and cash disbursements. In this case, cash is the company's most liquid asset or asset and is prone to fraud, fraud and theft. In this study, the objective is to find out how the accounting information system for cash receipts and payments on the internal control system at PT. Bulan Biru Tour and Travel. This type of research is a type of case study research using a qualitative approach. Internal cash control in the company is inadequate, this is reflected in the implementation of internal cash control, there is an organizational structure in which there is a description of the duties and responsibilities of each part of the company, the authorization of the authorized official for each transaction of cash receipts and disbursements of the company. It is suggested that there should be a separation of duties between the recording function and the cash storage function.
\end{abstract}

Keyword : Cash Disbursements, Cash Receipts, Internal Control Systems

\section{Pendahuluan}

Kemajuan teknologi membuat peranan suatu informasi menjadi sangat penting dalam hal untuk menunjang kemajuan sebuah perusahaan. Informasi yang cepat, tepat, akurat dan mampu berguna untuk dijadikan sarana bagi pihak manajemen perusahaan dalam mengelola sebuah perusahaan maupun dijadikan sebagai media pelaporan bagi pihak yang memiliki kepentingan dalam perusahaan. Hal ini mengharuskan suatu perusahaan untuk mendapatkan suatu informasi yang sesuai, tepat waktu, lengkap dan benar agar informasi tersebut dapat digunakan sebagai alat untuk pengambilan keputusan terkait dengan permasalahan yang terdapat dalam perusahaan. Untuk menunjang hal tersebut perusahaan diperlukan membuat suatu sistem untuk mengatur alur informasi yang dibutuhkan dalam perusahaan tersebut. Hal ini sesuai dengan (Zaki Baridwan, 2009), menjelaskan bahwa sistem adalah suatu kerangka dari prosedur-prosedur yang saling berhubungan yang disusun sesuai dengan suatu skema yang menyeluruh, untuk melaksanakan suatu kegiatan atau fungsi utama dari perusahaan.

Menurut (Laudon Kenneth C \& Laudon, 2012) sistem informasi adalah komponenkomponen yang saling berkaitan yang bekerja bersama-sama untuk mengumpulkan, mengolah, menyimpan, dan menampilkan informasi untuk mendukung pengambilan keputusan, koordinasi, pengaturan, analisa, dan visualisasi pada sebuah organisasi. Jadi, Sistem informasi merupakan suatu sistem yang memberikan berbagai macam data informasi yang digunakan untuk pihak manajemen dalam rangka pengambilan keputusan bagi perusahaan dan juga untuk melalukan kegiatan operasional dalam perusahaan, yang didalam sistem tersebut berisikan kombinasi dari manusia, teknologi dan dari prosedur yang dilakukan secara terorganisasi yang kemudian sistem tersebut menghasilkan suatu luaran berupa gambar, suara maupun tulisan. Dengan adanya suatu sistem informasi dalam perusahaan mampu 
menunjang kebutuhan perusahaan agar mampu mencapai tujuan perusahaan. Sistem informasi dalam perusahaan dapat berguna seperti meningkatkan aksebilitas data yang tersaji secara tepat waktu dan akurat untuk pengguna, mampu meningkatkan kinerja dengan efisiensi dan efektivitas proses secara keseluruhan dengan menghapus langkah-langkah yang kurang bernilai, memudahkan manajer untuk memantau, merencanakan dan mempertimbangkan dalam pengambilan keputusan, meningkatkan dalam pengambilan keputusan dan mampu memberdayakan karyawan sampai tingkat terendah.

Dalam bidang akuntansi, untuk mengatur fungsi akuntansi yang terdapat dalam sebuah perusahaan membutuhkan sistem informasi yang sering disebut sistem informasi akuntansi. Sistem informasi akuntansi merupakan organisasi yang terdiri formulir, catatan maupun laporan-laporan yang dibuat sedemikian rupa sebagai upaya dalam menyediakan suatu informasi keuangan yang diperlukan oleh pihak manajemen suatu perusahaan dalam upaya pengelolaan dan pengambilan keputusan perusahaan (Mulyadi, 2016). Sistem informasi akuntansi mempunyai bagian sangat penting dalam sebuah perusahaan. Sistem informasi akuntansi pada sebuah perusahaan berfungsi untuk menghasilkan laporan kepada pihak-pihak yang berkepentingan terhadap aktivitas ekonomi dan kondisi perusahaan, mengetahui maju mundurnya suatu perusahaan dari laporan keuangan perusahaan tersebut. Pemakai informasi akuntansi biasanya dipakai secara eksternal maupun internal. Sistem informasi akuntansi yang dirancang dan diimplementasikan sesuai dengan operasi perusahaan akan memperkuat sistem pengendalian internal. Salah satu tujuan sistem informasi akuntansi adalah menyediakan pengendalian yang memadai untuk keseluruhan transaksi sehingga transaksi yang dicatat benar dan sesuai.

Salah satu aktiva yang menunjang peranan penting dalam kegiatan perusahaan adalah kas. Menurut (Rusdianto, 2012), kas merupakan alat pertukaran yang dimiliki perusahaan dan siap digunakan dalam transaksi perusahaan, setiap saat diinginkan. Kas diperlukan untuk membiayai kegiatan operasional perusahaan setiap harinya, maupun untuk mengadakan investasi baru. Kas mempunyai pengaruh yang cukup besar terhadap keberlangsungan suatu perusahaan, dengan kata lain kelancaran kegiatan operasional perusahaan dan aktifitas perusahaan bergantung pada besar kecilnya kas yang tersedia dalam suatu perusahaan. Apabila kas dalam jumlah besar mampu membuat perusahaan dapat beroperasi dengan baik, mampu mengadakan suatu investasi dan menunjukkan tingginya tingkat likuiditas perusahaan tersebut. Kas salah satu aset yang sangat berpengaruh dalam neraca dalam penentuan suatu keputusan dalam perusahaan. Kas merupakan suatu komponen penting dalam kelancaran jalannya kegaiatan operasional suatu perusahaan.

Sumber kas terdiri dari dua kegiatan yaitu penerimaan dan pengeluaran kas. Kas dilihat dari sifatnya merupakan aset yang paling lancar dan hampir setiap transaksi dengan pihak luar selalu mempengaruhi kas. Kas merupakan komponen penting dalam kelancaran kegiatan operasional. Karena kas merupakan aset yang paling likuid, maka kas mudah digelapkan sehingga diperlukan pengendalian internal terhadap kas dengan memisahkan bagian-bagian yang ada. Seperti bagian pencatatan, akuntansi, dan pelaksanaan. Selain itu juga seharusnya diadakan pengawasan yang ketat terhadap bagian-bagian kas. Menurut (Soemarso S.R, 2010) tanpa adanya pengendalian internal akan mudah terjadi penggelapan uang kas.

Pengendalian internal adalah semua rencana organisasional, metode dan pengukuran yang dipilih oleh suatu perusahaan untuk kegiatan usaha dalam rangka mengamankan harta kekayaannya, mengecek keakuratan dan keandalan data akuntansi perusahaan, meningkatkan efisiensi operasional dan mendukung dipatuhinya kebijakan manajerial yang telah ditetapkan (Diana \& Setiawati, 2011).

Sistem pengendalian internal meliputi struktur organisasi, metode dan ukuran-ukuran yang dikoordinasikan untuk menjaga aset organisasi, mengecek keteliatan dan keandalan data akuntansi, mendorong efisiensi dan mendorong dipatuhinya kebijaksanaan manajemen (Mulyadi, 2016). Berdasarkan definisi tersebut pengendalian internal merupakan kegiatan 
yang dilakukan sebuah perusahaan untuk meminimalisir resiko-resiko yang akan muncul yang dapat merugikan perusahaan.

Suatu perusahaan yang menerapkan sistem pengendalian internal yang baik adalah perusahaan yang memisahkan tanggung jawab fungsional secara tegas dalam struktur organisasi, sistem otorisasi dan prosedur pencatatan yang baik, dan sumber daya yang memadai. Sistem pengendalian internal dijadikan sebuah sistem yang dimaksudkan untuk menghindari semua kemungkinan terjadinya kesalahan atau penyelewengan yang terjadi. Sistem pengendalian internal yang baik adalah dimana sebuah perusahaan mampu menekan terjadinya suatu kesalahan maupun penyimpangan yang mungkin akan terjadi. Fungsi pengendalian yang baik dengan berlandaskan pada sistem manajemen dan keuangan yang baik juga akan menciptakan aktivitas dalam perusahaan menjadi lancar dan terkendali (Diana \& Setiawati, 2011).

PT Bulan Biru Tour and Travel merupakan perusahaan jasa yang terletak dikawasan kabupaten Sidoarjo yang bergerak dibidang tour and travel. Menurut saudara Alvin selaku bagian administrasi sistem penerimaan dan pengeluaran kas yang terdapat dalam perusahaan sudah berjalan dengan baik. Tetapi masih belum adanya pemisahan antara transaksi penerimaan dan pengeluaran kas.

Pada PT Bulan Biru Tour and Travel ini memerlukan sistem pengendalian internal karena untuk menjaga keberadaan kas secara tepat untuk mengelola dan pengendalian terhadap kas, salah satunya dengan adanya sistem penerimaan kas dan pengeluaran kas. Dalam hal ini kas merupakan aktiva atau aset perusahaan yang paling likuid dan rentan terjadinya penyelewengan, penipuan dan pencurian.

Penerapan sistem informasi akuntansi penerimaan dan pengeluaran kas dalam perusahaan mampu mengoptimalkan kas yang masuk dan keluar serta mengatur jalannya kas. Sistem informasi akuntansi ini sangat penting, mengingat kas merupakan aktiva yang mudah berubah dibandingkan dengan aktiva lain, sehingga kas merupakan alat pembayaran yang selalu siap sedia untuk digunakan.

Sistem informasi akuntansi dalam sebuah perusahaan memegang peranan yang sangat penting untuk kelangsungan roda sebuah perusahaan, karena sistem informasi akuntansi mampu menyediakan kebutuhan informasi apapun yang diperlukan oleh pihak manajemen dan pemilik perusahaan dalam menentukan langkah-langkah kebijakan yang harus diambil dan yang akan digunakan. Sistem informasi akuntansi menekankan penyajian informasi yang memadai dan relevan bagi semua pihak yang berkepentingan, baik pihak eksternal maupun internal perusahaan. Pihak internal perusahaan adalah pihak manajemen perusahaan itu sendiri, yang meliputi semua pihak yang ada dalam lingkup perusahaan dan semua keputusan yang diambil akan berpengaruh terhadap organisasi didalam perusahaan. Sehingga sistem yang dibuat didalam suatu perusahaan harus efektif, informatif, dan akurat yang artinya sistem tersebut harus menyediakan informasi yang berkualitas bagi pihak-pihak yang membutuhkan, bebas dari kesalahan, mudah dipahami dan berguna bagi semua pihak yang berkepentingan.

Berdasarkan latar belakang diatas maka rumusan masalah yang timbul dalam objek penelitian ini yaitu Bagaimana sistem informasi akuntansi penerimaan dan pengeluaran kas terhadap sistem pengendalian internal pada PT. Bulan Biru Tour and Travel? Pada penelitian ini memiliki tujuan yaitu untuk mengetahui bagaimana sistem informasi akuntansi penerimaan dan pengeluaran kas terhadap sistem pengendalian internal pada PT. Bulan Biru Tour and Travel.

\section{Kajian Teori}

\subsection{Teori Normatif}

Menurut (Ghozali \& Anis, 2007) Teori normatif berusaha memberikan pedoman apa yang seharusnya dilakukan berdasarkan pertimbangan nilai (value judgement) yang digunakan dalam merumuskan teori. Sedangkan menurut (Suwardjono, 2013) menjelaskan bahwa sasaran teori akuntansi normatif hanyalah menghasilkan penjelasan mengapa perlakuan 
akuntansi lebih baik atau lebih efektif dibandingkan dengan perlakuan akuntansi lainnya, karena "tujuan akuntansi tertentu" harus dicapai. Teori normatif penuh dengan sarat dengan nilai karena untuk menentukan suatu praktik sesuai dengan tujuan yang telah ditetapkan untuk dicapai merupakan proses subjektif yang melibatkan kemampuan menimbang antara asas manfaat dan asas resiko.

Dari pengertian diatas, teori normatif berfokus pada preskripsi atau norma dan tidak dimaksudkan untuk pengembangan teori, yang diarahkan hanya untuk menjawab dan menjelaskan. Dengan demikian dapat dikatan bahwa hasil dari teori normatif adalah suatu pernyataan atau proposisi yang mengharuskan atau mewajibkan dalam proses akuntansi. Sebagai contoh, teori akuntansi normatif menghasilkan pernyataan bahwa diperlukannya suatu pengendalian internal yang baik untuk sistem informasi akuntansi penerimaan dan pengeluaran kas untuk menghindari dari kesalahan maupun hal yang tidak diinginkan.

\subsection{Sistem Informasi Akuntansi}

Sistem informasi akuntansi terdiri dari sekumpulan manusia maupun peralatan yang menunjang yang diatur untuk mengubah suatu data menjadi informasi yang nantinya akan dikomunikasikan dalam pengambilan sebuah keputusan yang digunakan sebuah perusahaan yang dilakukan secara manual maupun menggunakan sistem komputerisasi (Agustinus Mujilan, 2012). Sedangkan menurut (Mulyadi, 2016) berpendapat bahwa sistem informasi akuntansi terdiri dari organisasi formulir, catatan dan laporan yang dibuat sedemikian rupa yang menyediakan informasi keuangan yang dibutuhkan oleh pihak manajemen yang berguna bagi perusahaan. Dari pendapat para ahli dapat disimpulkan bahwa sistem informasi akuntansi dibuat untuk memudahkan dalam menyediakan suatu informasi keuangan yang dibutuhkan berbagai pihak dalam perusahaan yang dapat dijadikan sebagai pengambilan keputusan bagi perusahaan.

\subsection{Kas}

Menurut (Zaki Baridwan, 2009) kas merupakan suatu alat pertukaran yang digunakan sebagai ukuran dalam ilmu akuntansi. Yang dimaksud dengan pertukaran yaitu yang mampu digunakan sebagai pelunasan utang, dapat digunakan sebagai suatu setoran bank dengan jumlah yang sama sebesar nominal yang ada, dan juga simpanan atau kekayaan perusahaan yang disimpan dan dapat diambil sewaktu-waktu. Sumber kas terdiri dari dua kegiatan yaitu penerimaan dan pengeluaran kas. Menurut (Sujarweni, 2015) "Sistem penerimaan kas adalah suatu prosedur catatan yang dibuat untuk melaksanakan kegiatan penerimaan uang yang berasal dari berbagai macam sumbers yaitu dari penjualan tunai, penjualan aktiva tetap, pinjaman dan setoran modal baru". Menurut (Jusuf, 2005), siklus pengeluaran merupakan serangkaian aktivitas bisnis dan kegiatan pengolahan data yang berhubungan dengan pembelian dan pembayaran atas barang dan jasa yang dibeli.

\subsection{Sistem Pengendalian Internal}

Dengan menggunakan sistem pengendalian internal yang baik, perusahaan mampu menghindari maupun meminimalisir kecurangan-kecurangan yang akan terjadi didalam perusahaan. Salah satu sistem yang baik bagi perusahaan adalah sistem pengendalian internal. Sistem pengendalian internal menurut IAPI (2011:319.2) sebagai suatu proses yang dijalankan oleh dewan komisaris, manajemen dan entitas lain yang didesain untuk memberikan keyakinan memadai tentang pencapaian dalam keandalan pelaporan keuangan, efektivitas dan efisiensi operasi dan kepatuhan terhadap hukum dan peraturan yang berlaku. Menurut (Mulyadi, 2016) sistem pengendalian internal meliputi struktur organisasi, metode dan ukuran-ukuran yang dikoordinasikan untuk menjaga aset organisasi, mengecek ketelitian dan keandalan data akuntansi, mendorong efisiensi dan mendorong dipatuhinya kebijakan manajemen. Sistem pengendalian internal adalah suatu proses yang dibuat untuk memberikan jaminan keamanan bagi unsur-unsur yang ada di dalam perusahaan. 


\section{Metode Penelitian}

Jenis penelitian yang digunakan adalah jenis penelitian studi kasus dengan menggunakan pendeketan kualitatif. Dapat dikatakan sebagai penelitian kualitatif karena berupaya untuk mengungkapkan suatu masalah dan keadaan sebagaimana keadaan sebenarnya. Fokus penelitiannya yaitu sistem informasi akuntansi penerimaan dan pengeluaran kas terhadap sistem pengendalian internal pada PT. Bulan Biru Tour and Travel. Dalam hal pengambilan sampel menggunakan teknik purposive sampling. Penelitian ini menggunakan data primer dan data sekunder. Data primer yang dilakukan melalui pengamatan dan wawancara di lapangan, sedangkan data sekunder berasal dari catatan-catatan yang dimiliki perusahaan. Teknik pengumpulan data menggunakan teknik wawancara, pengamatan, dan dokumentasi. Instrumen penelitian ini adalah peneliti sendiri karena penelitian ini menggunakan metode kualitatif. Teknik analisis data dalam penelitian ini menggunakan reduksi data setelah penelitian, penyajian data yang diperolah dari penelitian, dan conclusion drawing yang berisikan kesimpulan awal setelah kegiatan penelitian selesai dilakukan.

\section{Hasil Dan Pembahasan}

\subsection{Hasil Penelitian}

\subsubsection{Sistem Otorisasi dan Pencatatan}

Semua transaksi yang ada dalam perusahaan harus mendapatkan otorisasi dari pejabat yang berwenang dan harus dicatat sesuai dengan ketentuan yang berlaku. Transaksi-transaksi yang sering terjadi terdiri dari transaksi penerimaan dan pengeluaran kas. Setiap transaksi hanya terjadi atas dasar otorisasi dari pejabat yang memiliki wewenang untuk menyetujui terjadinya transaksi tersebut. Sistem wewenang dan prosedur pencatatan akan memberikan perlindungan terhadap kekayaan perusahaan. Dengan demikian, didalam organisasi disusun sistem otorisasi agar dapat mempertanggungjawabkan setiap transaksi yang ada diperusahaan. Berikut ini adalah sistem otorisasi dan prosedur pencatatan yang terdapat pada PT. Bulan Biru Tour and Travel:

\section{Penerimaan Kas}

a. Bagian administrasi dan keuangan mencatat setiap penerimaan kas yang sifatnya merupakan kegiatan operasional dan non operasional.

b. Setiap pendapatan yang masuk dicatat dalam pendapatan perusahaan dan dicatat dalam laporan periodik berserta laporan setiap perjalanan wisata apabila pengeluaran digunakan untuk keperluan perjalanan wisata.

c. Setiap pendapatan yang belum tertagih bagian administrasi dan keuangan mencatatnya dalam laporan periodik dengan kolom rencana pendapatan yang dibuat dengan sistem periodik mingguan, dan untuk pelanggan yang telah melakukan pelunasan dicatat dalam laporan periodik dengan kolom pendapatan.

d. Pencatatan invoice dilakukan dengan menggunakan 1 nomor surat yang sama untuk seluruh transaksi penerimaan kas.

e. Untuk pengendalian dana penerimaan kas masuk perusahaan yang berwenang mengisi adalah bagian administrasi dan keuangan. Bagian administrasi dan keuangan juga harus menyertakan bukti pemasukan kas yaitu Form Kas Masuk yang disebut dengan KM yang harus diserahkan kepada bendahara untuk diotorisasi.

f. Untuk otorisasi perusahaan ini sudah memiliki sistem yang baik. Bukti-bukti transaksi dicatat dan diarsip dengan baik. Akan tetapi penomoran invoice hanya menggunakan 1 nomor surat yang sama untuk seluruh transaksi penerimaan kas.

\section{Pengeluaran Kas}

a. Bagian administrasi dan keuangan mencatat setiap pengeluaran kas yang sifatnya merupakan kegiatan operasional dan non operasional. 
a. Untuk pengeluaran kas yang ada pada bagian administrasi dan keuangan yang menyediakan saldo 1.500.000 ribu rupiah tanpa ada batasan waktu tertentu, jumlah nominal kas yang terdapat pada bagian adiministrasi dan keuangan sewaktu-waktu bisa lebih atau kurang dari 1.500.000 ribu rupiah sesuai dengan kebutuhan pengeluaran kas perusahaan.

b. Setiap pengeluaran kas perusahaan dicatat dalam kolom pengeluaran kas dan dicatat dalam laporan periodik beserta laporan setiap perjalanan wisata apabila pengeluaran digunakan untuk keperluan perjalanan wisata.

c. Untuk pengendalian dana pengeluaran kas keluar perusahaan yang berwenang mengisi adalah bagian administrasi dan keuangan. Bagian administrasi dan keuangan juga harus menyertakan bukti pengeluaran kas yaitu Form Kas Keluar yang disebut dengan KK yang harus diserahkan kepada bendahara untuk diotorisasi.

d. Untuk otorisasi perusahaan ini sudah memiliki sistem yang baik. Bukti-bukti transaksi dicatat dan diarsip dengan baik.

\subsubsection{Praktik Yang Sehat}

Praktik yang sehat dalam melaksanakan tugas dan fungsi setiap bagian yang ada dalam sebuah perusahaan. Pembagian tanggungjawab fungsional dan sistem otorisasi dan prosedur pencatatan yang telah ditetapkan tidak akan terlaksana dengan baik jika tidak diciptakan cara-cara untuk menjamin praktik yang sehat dalam pelaksanaannya. Untuk menciptakan praktik yang sehat harus terdapat karyawan yang kompeten dalam melaksanakan tugasnya. Karena karyawan merupakan komponen kunci dalam perkembangan suatu perusahaan. Cara yang dilakukan PT. Bulan Biru Tour and Travel dalam menunjang praktik yang sehat, antara lain:

1. Melaksanakan pencocokan catatan saldo kas bagian administrasi dan keuangan dengan bukti penerimaan dan pengeluaran kas yang ada dengan bendahara. Bagian administrasi dan keuangan harus mempertanggungjawabkan semua laporan keuangan dan catatan saldo kas perusahaan yang dibuat. Menurut standart peraturan yang ada dalam perusahaan antara bagian administrasi dan keuangan harusnya melakukan pencocokan setiap hari, pada saat menjelang jam pulang kantor.

2. Adanya pemeriksaan secara berkala yang dilakukan pimpinan terhadap kinerja para karyawannya dalam melaksanakan tanggungjawabnya maupun tugas yang diberikan.

3. Invoice bernomor urut cetak, akan tetapi hanya menggunakan 1 nomor urut yang digunakan untuk semua transaksi. Hal ini terkadang menyebabkan kesalahan karena seluruh transaksi penerimaan kas menggunakan 1 nomor urut saja.

4. Tidak adanya pemisahan tugas sehingga setiap transaksi dari awal hingga akhir hanya dikerjakan bagian administrasi dan keuangan, tanpa ada campur tangan dari bagian lain.

5. Adanya komunikasi yang baik antara pimpinan perusahaan dengan karyawan tetapi tetap memperhatikan batasan dan jarak yang jelas. Hal ini dilakukan untuk menimbulkan rasa segan serta menjaga wibawa agar karyawan tidak melampaui batas dan tetap menjalankan peraturan yang ada.

6. Dalam satu tahun perusahaan menjadwalkan adanya perjalanan wisata untuk karyawannya, yang berguna untuk membangun kekompakan serta kedekatan satu sama lain dalam menjalin kerja sama didalam perusahaan.

\subsubsection{Kompetensi Karyawan}

Karyawan adalah salah satu komponen penting dalam perkembangan sebuah perusahaan guna menciptakan praktik yang sehat, maka dari itu dalam perusahaan terdapat karyawan yang kompeten dalam bidangnya. Kualifikasi yang ditetapkan 
dalam setiap posisi pekerjaan dalam perusahaan, harus merefleksikan tingkat tanggungjawab yang berkaitan dengan posisi tersebut. Awal PT. Bulan Biru Tour and Travel terbentuk, karyawannya hanya ada 4 orang saja.

Namun seiring berjalannya waktu, dan bertambahnya pelanggan serta makin besar nilai dalam transaksi maka dibutuhkan wakil direktur dan bagian keuangan untuk memudahkan kegiatan operasional. Para staff lain seperti marketing, humas, personalia, bendahara dan komisaris juga dibutuhkan untuk menjadikan perusahaan semakin professional dan berkembang. Untuk setiap penerimaan karyawan baru akan dilakukan oleh Bagian Personalia namun hasil akhir akan tetap diserahkan kepada direktur dan wakil direktur.

\subsubsection{Penerapan Pengendalian Intern Kas Perusahaan}

Dasar yang digunakan PT. Bulan Biru Tour and Travel dalam pencatatan transaksi sebagai berikut:

1. Setiap transaksi harus memiliki bukti fisik seperti kwitansi, nota dan bukti lain yang terdapat cap nama took serta nomor telepon, dan alamat jelas.

2. Setelah transaksi dilakukan atas otorisasi yang berwenang dan wajib dilaporkan kepada pimpinan.

3. PT. Bulan Biru Tour and Travel juga memiliki account rekening bank yang berbeda dengan pemilik perusahaan.

4. Dokumen - dokumen yang dikeluarkan perusahaan yaitu :

a. Invoice

Invoice yang dikeluarkan didalamnya berisikan detail seluruh persewaan mobil maupun busa atau detail perjalanan paket wisata , nominal yang harus dibayar, besar discount yang diberikan, jumlah uang yang dibayarkan (DP / lunas). Pada invoice juga berisikan 2 tanda tangan yaitu kolom untuk bagian administrasi dan keuangan serta pelanggan. Dicetak 2 kali diberikan kepada pelanggan dan untuk arsip perusahaan.

b. Kwitansi

Kwitansi pada PT. Bulan Biru Tour and Travel kurang lebih sama dengan kwitansi pada umumnya terdapat nominal angka, nominal secara huruf terbilang, keterangan berisikan untuk pembayaran atas persewaan atau perjalananan wisata dan logo perusahaan.

c. Cek

Cek yang ada pada PT. Bulan Biru Tour and Travel pun juga sama dengan cek pada umumnya, cek standart yang dikeluarkan oleh bank yang dimiliki oleh perusahaan.

Dari poin pertama bertujuan untuk meminimalisir adanya penyalahgunaan terhadap uang kas yang ada dalam perusahan yang dapat merugikan perusahaan dan pelanggan. Sedangkan untuk poin kedua dan ketiga bertujuan agar setiap jenis transaksi lebih mudah diketahui berapa jumlah pengeluaran dan pendapatan yang diperoleh. Sehingga akan lebih mudah untuk melakukan pengendalian. Pengendalian internal kas sangat penting dilaksanakan pada setiap perusahaan, PT. Bulan Biru Tour and Travel menerapkan pengendalian internal kas dengan memperhatikan komponenkomponen yang ada yaitu:

1. Lingkungan Pengendalian

Didalam lingkungan pengendalian menggambarkan sikap dan tindakan pihak manajemen mengenai pengendalian perusahaan. Lingkungan pengendalian memiliki hubungan yang erat dengan kinerja operasional yang ada dalam perusahaan. Sehingga hal tersebut secara langsung akan menentukan budaya organisasi sebuah perusahaan yang terdiri dari:

a) Struktur Organisasi 
Struktur organisasi yang ditetapkan PT. Bulan Biru Tour and Travel disusun secara jelas dan sistematis, namun secara pelaksanaan seluruh karyawan dituntut untuk tidak hanya mengerjakan pekerjaan yang lain yang bukan tanggungjawabnya. Sehingga fungsi yang ada dalam perusahaan terlihat kurang jelas untuk pemisahan tugas dan fungsinya. Namun cukup baik dan memudahkan karyawan yang pada saat itu absen atau berhalangan hadir tetapi kegiatan operasional tetap dapat berjalan dengan baik.

b) Pendelegasian Wewenang dan Tanggung Jawab

Hal tersebut telah diuraikan dengan jelas dan tertulis dalam struktur organisasi dan kontrak kerja yang telah ditanda tangani antara karyawan dengan perusahaan pada saat awal diterima untuk bekerja. Namun apabila disana ada pekerjaan tambahan yang harus dikerjakan oleh karyawan, pimpinan akan langsung memberikan tugas tersebut secara lisan tanpa ada surat khusus yang mendelegasikan wewenang kepada penerimanya kemudian pimpinan memantau dengan cara karyawan harus memberikan laporan harian secara rutin. Sehingga dengan demikian karyawan dapat menyampaikan apabila terdapat kendalakendala selama pengerjaan tugas tersebut, dan pimpinan juga dapat mengetahui bahwa waktu yang ada telah dipergunakan karyawan secara maksimal untuk pekerjaan.

c) Kebijakan Perusahaan

Pimpinan PT. Bulan Biru Tour and Travel dalam membuat ataupun menentukan kebijakan perusahaan telah sesuai dengan peraturan departemen ketenagakerjaan atau Depanaker. Seperti dengan cara memberikan gaji yang memadai atau sesuai dengan Upah Minimum Kerja (UMK), durasi kerja selama delapan jam. Namun adapula kebijakan yang dibuat berdasrkan kejadian atau pelanggaran yang dibuat oleh karyawan sehingga perusahaan membuat kebijakan untuk menghindari agar tidak terjadi kembali, seperti:

- Dilarang menerima tip dari klien dengan alasan apapun

- Memberikan keterangan apabila tidak masuk kerja sebelum pukul 10.00

2. Perkiraan Resiko yang Timbul

Resiko yang mungkin timbul telah diidentifikasi, analisis dan dikelola dengan baik oleh perusahaan sehingga dapat mempermudah pelaksanaan pengendalian internal dan mengurangi adanya penyimpangan dalam perusahaan. Hal ini tercermin dari beberapa hal berikut:

a) Perlakuan Terhadap Karyawan

Adanya karyawan baru yang memiliki semangat kerja yang tinggi mampu membangkitkan semangat karyawan lainnya untuk bekerja dengan lebih baik lagi. Selain itu, terdapat gagasan baru maupun pandangan lain atas pengendalian internal yang sedang diterapkan dalam perusahaan yang membantu apabila karyawan tersebut berkualitas baik. Untuk merekrut karyawan yang sesuai dengan standart, perusahaan mengadakan seleksi dengam wawancara, tes tulis (terdiri dari tes psikologi dan tes pengetahuan sesuai dengan bidang yang dilamar) serta harus melalui masa percobaan (training) terlebih dahulu selama tiga bulan. Selain itu perusahaan juga mengadakan pelatihan terhadap karyawan yang dapat meningkatkan keahlian karyawan-karyawannya.

b) Pemanfaatan Teknologi Baru

PT. Bulan Biru Tour and Travel telah menggunakan sistem yang bersifat komputerisasi dalam membuat bukti-bukti transaksi perusahaan, sehingga mampu meminimalkan kecurangan atau penyimpangan yang terjadi dan mengefisiensikan atau menghemat waktu kerja. Bahkan untuk slip gaji serta 
rekap daftar kehadiran karyawan dilakukan dengan menggunakan komputerisasi. 3. Aktivitas Pengendalian

Penerimaan kas pada PT. Bulan Biru Tour and Travel diperoleh dari jasa persewaan dan perjalanan wisata domestik. Piutang yang terjadi pada perusahaan biasanya sudah memiliki kesepakatan perjanjian dengan klien ataupun pelanggan yang telah mempunyai jangka waktu tertentu sesuai dengan kesepakatan diawal dan diberikan kemudahan untuk melakukan angsuran sesuai dengan kurun waktu yang diberikan pada saat perjanjian.

Bagian administrasi dan keuangan membuat invoice berdasarkan perjanjian sewa serta proposal penawaran yang dibuat oleh marketing dan humas, sebagai bukti untuk melakukan penagihan pada pelanggan. Kemudian pelanggan akan memberikan konfirmasi pada marketing ataupun bagian administrasi dan keuangan bahwa akan melakukan pembayaran dengan cara transfer bank atau cash. Setelah melakukan pembayaran, maka marketing akan memberikan konfirmasi pada bagian administrasi dan keuangan. Apabila pembayaran melalui transfer bank, maka bagian administrasi dan keuangan akan melakukan pengecekan saldo bank terlebih dahulu, setelah dapat dipastikan uang telah diterima maka bagian administrasi dan keuangan akan membuat Invoice dan kwitansi. Kemudian pada sore hari menjelang jam pulang kantor apabila dirasa sudah tidak akan ada transasksi kembali bagian administrasi dan keuangan akan menyerahkan seluruh bukti-bukti transaksi beserta dokumen-dokumen pendukungnya akan diperiksa dengan bagian bendahara dan dilakukan otorisasi dengan cara diparaf. Setelah diotorisasi dengan bendahara akan diberikan kepada pimpinan untuk dilakukan otorisasi, kemudian seluruh dokumendokumen akan diserahkan kebali kepada bagian administrasi dan keuangan untuk diarsip.

Aktivitas pengendalian meliputi kebijakan dan prosedur yang diperlukan dalam tindakan untuk meminimalkan risiko yang akan terjadi dalam proses untuk mencapai tujuan perusahaan. Unsur-unsur aktivitas pengendalian sebagai berikut:

a) Pelaksanaan Review

Pelaksanaan review dilakukan dengan mekanisme pencocokan atau perbandingan antara pencatatan dengan bukti transaksi yang dilakukan. Tinjauan ulang atas pelaksanaan kerja dilakukan oleh direktur maupun wakil direktur terhadap bagian-bagian yang terdapat dalam perusahaan. Jika terjadi kesalahan atau penyimpangan maka akan dilakukan tindakan koreksi.

Tinjauan ulang tersebut bisa juga dilakukan dengan adanya pemeriksaan mendadak, seperti memeriksa catatan penerimaan dan pengeluaran kas dengan bukti pendukungnya.

b) Pengendalian Fisik

Pengendalian fisik terdiri dari prosedur-prosedur pengamanan atas kekayaan dan catatan perusahaan. Kegiatan pengendalian fisik ini dilakukan untuk menjaga kekayaan perusahaan dan menghindari pencurian atas asset. PT. Bulan Biru Tour and Travel telah melaksanakan pengamanan yang baik yaitu dengan adanya pengamanan 24 jam dengan CCTV yang online selama 24 jam dan juga terdapat brangkas berbeda yang dikunci untuk menyimpan uang dan catatan penting perusahaan.

c) Pemisahan Tugas

Tujuan utama pemisahan tugas adalah untuk menghindari timbulnya kesalahan-kesalahan yang disengaja maupun tidak disengaja dalam mencatat transaksi, mengotorisasi transaksi dan pemeliharaan asset. Pemisahan tugas yang ada dalam PT. Bulan Biru Tour and Travel yaitu:

1) Fungsi Otorisasi 
Wewenang otorisasi semua transaksi penerimaan dan pengeluaran kas pada bendahara perusahaan. Akan tetapi fungsi otorisasi tertinggi terletak pada pimpinan perusahaan sehingga semua transaksi harus melalui persetujuan perusahaan.

2) Fungsi Pengawasan

Fungsi ini dilaksanakan oleh masing-masing bagian yang bersangkutan, terutama direktur dan wakil direktur. Dalam hal ini pengawasan kas dilakukan oleh bendahara perusahaan.

3) Fungsi Pencatatan

Fungsi pencatatan bertugas untuk mencatat transaksi-transaksi yang terjadi dalam perusahaan serta sebagai informasi pelaporan pertanggungjawaban baik penerimaan dan pengeluaran kas. Fungsi ini dilakukan oleh bagian administrasi dan keuangan (laporan keuangan periodik dan laporan perjalanan wisata) beserta bendahara (laporan keuangan).

4) Fungsi Penyimpanan

Fungsi penyimpan bertugas untuk menyimpan uang kas yang terdapat dalam perusahaan yang digunakan untuk kegiatan operasional perusahaan. Fungsi ini dilakukan oleh bagian administrasi dan keuangan serta penyimpanan bukti-bukti transaksi.

\subsubsection{Pengelolaan Kas Pada PT. Bulan Biru Tour and Travel}

Adapun pengelolaan kas yang teradapat pada PT. Bulan Biru Tour and Travel adalah sebagai berikut:

1. Penerimaan Kas Perusahaan

Penerimaan kas perusahaan berasal dari penerimaan dana pelanggan untuk melakukan sewa ataupun untuk melakukan perjalanan wisata dikurangi dengan biaya-biaya yang timbul. Dimana biaya tersebut dikelola sedemikian rupa sehingga menghasilkan selisih yang nantinya selisih tersebut merupajan pendapatan perusahaan. Dana dari pelanggan terkadang tidak langsung dibayarkan dalam satu waktu namun dibayarkan dua sampai tiga kali pembayaran.

2. Penerimaan Kas Kecil

Pengelolaan kas kecil sepenuhnya ditangani oleh bagian administrasi dan keuangan namun dalam beberapa transaksi akan tetap melibatkan bendaharan dan pimpinan perusahaan. Adapun prosedur serta ketentuan dalam melaksanakan transaksi penerimaan kas kecil yang dapat dijelaskan sebagai berikut:

Bagian pemegang kasa kecil dalam perusahaan ini adalah bagian administrasi dan keuangan yang bernama Alvian Firdaus. Perusahaan menetapkan saldo kas kecil yaitu 1.500.000 ribu rupiah. Pengisian kas kecil tidak memiliki jadwal khusus untuk dilakukan, hanya disesuaikan dengan biaya yang dikeluarkan pada saat itu, apabila jumlah kas kecil tidak mencukupi maka bagian administrasi dan keuangan akan mengambil uang tunai dari bank dengan melakukan konfirmasi terlebih dahulu kepada bendahara dan pimpinan perusahaan. Seluruh transaksi kas kecil yang terjadi dengan penerimaan kas, bagian administrasi dan keuangan berkewajiban membuat Form Kas Masuk atau bukti kas masuk yang setiap menjelang jam pulang kantor akan diberikan kepada bendahara dan pimpinan perusahaan untuk dilakukan validasi, kemudian di arsip. Sumber dari penerimaan kas kecil antara lain:

- Penerimaan pelunasan atau pembayaran dari klien yang dibayarkan secara tunai.

- Kas yang diambil dari rekening bank perusahaan.

3. Pengeluaran Kas

Transaksi pengeluaran kas perusahaan pada PT. Bulan Biru Tour and Travel antara lain yaitu: 
- Biaya Gaji

- Biaya Listrik

- Biaya Internet

- Biaya Telepon

- Biaya Pajak

- Biaya Pembelian Aset Perusahaan

- Biaya Sewa pada pihak ketiga

Untuk pembayaran pada pihak ketiga akan dilakukan setelah perusahaan menerima pembayaran dari pelanggan ataupun sesuai dengan perjanjian yang dibuat antara perusahaan dengan pihak ketiga. Bagian administrasi dan keuangan yang bertugas untuk mentransfer ke rekening ke pihak ketiga.

4. Pengeluaran Kas Kecil

Pengeluaran kas kecil perusahaan memiliki sistem yang sama dengan penerimaan kas kecil, bahwa setiap pengeluaran yang terjadi pad kas kecil harus dicatat dan dibuatkan bukti dalam Form Kas Keluar atau bukti kas keluar sesuai dengan tanggal terjadinya transaksi yang menjelang jam pulang kantor akan diserahkan kepada bendahara dan pimpinan untuk divalidasi serta dilampirkan bukti penunjang lainnya. Pengeluaran kas kecil pada PT. Bulan Biru Tour and Travel merupakan pengeluaran yang digunakan untuk kebutuhan operasional perusahaan secara rutin, seperti:

- Pembelian peralatan kantor

- Pembayaran jasa sopir, bensin dan parkir

\subsection{Pembahasan}

Dalam pengelolaan kas tentu sangat erat kaitannya dengan transaksi penerimaan kas. Dalam penerimaan dan pengeluaran kas terdapat unsur-unsur sistem pengendalian internal yaitu:

a. Struktur organisasi yang memisahkan tanggung jawab dan wewenang secara tegas.

Dalam struktur organisasi bagian-bagian yang dalam perusahaan sudah menggambarkan adanya pemisahan tanggungjawab dan wewenang secara tegas. Akan tetapi dalam sistem penerimaan kas masih belum adanya pemisahan tugas antara fungsi pencatatan dan fungsi penyimpanan kas masih belum ada pemisahan tugas. Yang bertanggungjawab dalam hal tersebut adalah bagian administrasi dan keuangan. Bagian pencatatan dan penyimpanan kas sebaiknya dipisahakan karena untuk menghindari penyalahgunaan catatan kas. Belum adanya pemisahan fungsi pencatatan dan fungsi penyimpanan kas membuat prosedur pengeluaran kas kurang sesuai dan belum meadai, karena kurangnya keakuratan catatan akuntansi.

b. Sistem otorisasi dan prosedur pencatatan.

Dalam organisasi, setiap transaksi hanya terjadi atas dasar otorisasi dari pejabat yang memiliki wewenang untuk menyetujui terjadinya transaksi tersebut. Berdasarkan hasil wawancara peneliti, perusahaan telah menerapkan hal tersebut. Seperti kas masuk menggunakan form kas masuk dan untuk pengeluaran kas menggunakan form kas keluar yang diotorisasi oleh bendahara perusahaan.

c. Praktik yang sehat.

Dalam perushaan ini praktik yang sehat sudah diterapkan dengan adanya pencocokan catatan saldo kas bagian administrasi dan keuangan dengan bukti penerimaan dan pengeluaran kas yang terjadi dengan bendahara perusahaan. Adanya pemeriksaan secara berkala yang dilakukan pimpinan terhadap kinerja para 
karyawannya dalam melaksanakan tanggungjawabnya maupun tugas yang diberikan. Akan tetapi invoice bernomor urut cetak yang digunakan hanya 1 nomor urut yang digunakan untuk semua transaksi. Hal ini terkadang menyebabkan kesalahan karena seluruh transaksi penerimaan kas menggunakan 1 nomor urut saja.

d. Karyawan yang mutunya sesuai dengan tanggung jawabnya.

Karyawan kompeten yang sesuai dengan tanggungjawabnya sudah dimiliki oleh perusahaan. Hal ini dibuktikan dengan bagian administrasi dan keuangan yang membuat laporan keuangan dan mampu untuk dipertanggungjawabkan kepada bendahara maupun pimpinan perusahaan.

Sistem pengendalian internal pada perusahaan PT. Bulan Biru Tour and Travel masih kurang memadai karena salah satu unsur pengendalian internalnya belum terpenuhi. Berikut ini penjelasannya:

1. Lingkungan Pengendalian Perusahaan

Lingkungan pengendalian merupakan dasar utama dalam sistem pengendalian internal. Didalam lingkungan ini tercermin sikap dan tindakan yang berkaitan erat dengan penrusahaan, lingkungan pengendalian yang ada di PT. Bulan Biru Tour and Travel telah memadai, terbukti dari perusahaan yang telah memiliki visi misi kerja operasi yang telah membentuk sebuah ciri atau budaya khusus dalam perusahaan mengenai kinerja dari para karyawan yang ada dalam perusahaan. Lingkungan pengendalian dapat dilihat dari:

a) Visi Misi Perusahaan dan Gaya Operasi

Visi misi perusahaan mampu menggambarkan tujuan perusahaan yang menajdi parameter bagi perusahaan dan karyawannya dalam mencapai tujuan yang diinginkan oleh perusahaan. Gaya operasi merupakan gaya pencerminan terhadap kegiatan operasional perusahaan harus dilakukan. Visi misi perusahaan PT. Bulan Biru Tour and Travel yaitu memberikan jasa layanan perjalanan wisata yang berkualitas dan dipercaya banyak orang. Hal ini sudah terwujud melalui banyaknya pelanggan yang sudah melakukan kegiatan perjalanan dengan PT. Bulan Biru Tour and Travel.

b) Struktur Organisasi

Struktur organisasi bila di refleksikan dengan efektifitas perusahaan yang bergerak dalam bidang jasa sudah cukup memadai. Hal ini tercermin dalam struktur organisasi perusahaan yang mampu menjelaskan adanya tugas, wewenang dan tanggungjawab yang ada dalam perusahaan.

c) Kebijakan Pimpinan Perusahaan

Pimpinan PT. Bulan Biru Tour and Travel dalam membuat ataupun menentukan kebijakan perusahaan telah sesuai dengan peraturan departemen ketenagakerjaan atau Depanaker. Seperti dengan cara memberikan gaji yang memadai atau sesuai dengan Upah Minimum Kerja (UMK), durasi kerja selama delapan jam.

2. Perkiraan Resiko yang Muncul

PT. Bulan Biru Tour and Travel juga telah memperhatikan dari segi meminimalisir resiko yang aka terjadi. Hal ini terlihat dari adanya persyaratan atau kompetensi karyawan sebelum bekerja di perusahaan. Adanya kompetensi jaryawan ini bertujuan supaya untuk karyawan baru yang akan bekerja dan bergabung dalam perusahaan. Adanya kompetensi karyawan ini bertujuan supaya karyawan baru yang akan bekerja dan bergabung dalam perusahaan bisa menjalankan tugas yang diberikan dengan baik sesuai dengan tanggungjawab yang diberikan perusahaan kepada para karyawan. PT. Bulan Biru Tour and Travel juga memperhatikan dari sisi absensi karyawan. Dikarenakan PT. Bulan Biru Tour and Travel merupakan sebuah 
perusahaan yang bergerak dibidang jasa untuk wisata yang waktu pelayanannya hingga jam 12 malam dini hari, maka keluar masuk kantor pada waktu diluar jam-jam kantor sangat mungkin dan wajar untuk terjadi. Namun banyak juga karyawan yang terlambat masuk kerja maupun tidak berada dikantor pada saat jam kantor mengatasnamakan kepentingan perusahaan. Untuk mengantisipasi penyalahgunaan kepentingan, perusahaan membuat sebuah peraturan, bagi seluruh karyawan yang akan meninggalkan kantor diwajibkan untuk melakukan perijinan melalui HRD. Namun apabila karyawan yang sedang dilapangan atau diluar kota tidak perlu datang ke kantor terlebih dahulu hanya untuk melakukan absensi, melaikan karyawan dapat mengirimkan dokumentasi perjalanan wisata maupun pengantaran pelanggan dengan format yang sudah ditentukan perusahaan kemudian dikirimkan kepada HRD.

3. Informasi dan Komunikasi

Informasi dan komunikasi pada perusahaan PT. Bulan Biru Tour and Travel telah berjalan cukup baik, terjalinnya komunikasi yang interaktif antara pimpinan dan karyawan ataupun sesama karyawan, maka pembuatan dan penyajian informasi serta komunikasi antara bagian-bagian yang ada dalam di PT. Bulan Biru Tour and Travel berjalan dengan baik tanpa ada rasa tegang. Seperti beberapa kejadian yang terjadi berikut ini:

a) Setiap selesai melakukan perjalanan wisata, bagian marketing dan bagian humas memberikan report langsung secara lisan kepada pegawai kantor mengenai perjalanan wisata tersebut.

b) Setiap tugas yang diberikan pimpinan perusahaan maka diharuskan memberi laporan mengenai hasil maupun perkembangannya.

c) Bagian administrasi dan keuangan tidak mempersulit dalam mengeluarkan uang kas perusahaan untuk kepentingan perjalanan wisata dengan syarat terdapat nota-nota yang jelas mengenai biaya-biaya tersebut.

d) Bagian administrasi dan keuangan melaporkan semua pengeluaran dan pemasukan kas perusahaan kepada pimpinan perusahaan secara jelas.

4. Pemantauan

Pemantauan yang dilakukan pihak-pihak yang terkait terutama pimpinan perusahaan dilakukan dengan sangat baik, hal ini dapat terlihat dari keseharian pimpinan apabila mendelegasikan suatu tugas, maka pimpinan akan rutin menanyakan perkembangan maupun kesulitan yang dialami karyawannya. Sehingga semakin mendukung pelaksanaan pengendalian internal.

5. Aktivitas Pengendalian

Aktivitas Pengendalian dalam PT. Bulan Biru Tour and Travel menurut standart yang telah dibuat oleh pimpinan perusahaan adalah setiap harinya menjelang pulang kantor bagian administrasi dan keuangan harus melakukan pencocokan transaksi penerimaan dan pengeluaran kas dengan bukti-bukti yang ada. Namun pada kenyataannya hal tersebut tidak dapat dilakukan karena beberapa hal seperti adanya kepentingan yang lain dan kesibukan dalam bekerja. Sehingga hal ini kemudian dilakukan maksimal dua kali dalam seminggu.

\section{Kesimpulan dan Saran}

\subsection{Kesimpulan}

Berdasarkan hasil penelitian yang dikemukakan diatas, peneliti menarik kesimpulan yaitu sistem pengendalian internal kas yang ada dalam perusahaan kurang memadai, hal ini karena tercermin pada pelaksanan pengendalian internal kas terdapat struktur organisasi yang didalamnya terdapat penjelasan tugas dan tanggungjawab setiap bagian-bagian yang ada pada perusahaan, adanya otorisasi dari pejabat yang berwenang untuk setiap transaksi penerimaan dan pengeluaran kas perusahaan, adanya pelaksanaan monitoring terhadap laporan 
penerimaan dan pengeluaran kas yang diterima oleh pejabat yang terkait, adanya pencocokan saldo antara bagian administrasi dan keuangan dengan bendahara, semua bukti transaksi diarsip dengan baik dan tidak adanya pemisahan tugas antara fungsi pencatatan dan penyimpanan kas serta pencatatan invoice hanya menggunakan 1 nomor urut cetak untuk semua jasa sewa.

\subsection{Saran}

Berdasarkan hasil penelitian, penulis ingin memberikan saran untuk memperbaiki kelemahan-kelemahan yang terdapat pada PT. Bulan Biru Tour and Travel. Adapun saran tersebut yaitu disarankan agar adanya pemisahan tugas antara fungsi pencatatan dan fungsi penyimpanan kas. Pemisahan antara fungsi pencatatan dan fungsi penyimpanan kas dilakukan untuk menghindari penyalahgunaan catatan kas perusahaan. Dan disarankan agar perusahaan menggunakan invoice dengan nomor urut cetak yang berbeda untuk setiap jasa sewa yang ada. Cara ini dapat dilakukan dengan memberikan kode yang berbeda untuk setiap transaksi penyewaan. Hal ini bertujuan agar data yang disimpan lebih terkelompokkan dan pada saat dibutuhkan tidak kesulitan dalam mencari.

\section{Referensi}

Agustinus Mujilan. (2012). Sistem Informasi Akuntansi (1st ed.). Wima pers.

Diana, A., \& Setiawati, L. (2011). Pengertian sistem menurut Anastasia Diana \& Lilis Setiawati. In Sistem Informasi Akuntansi.

Ghozali, I., \& Anis, C. (2007). Teori Akuntansi (Edisi Keti). BP-UNDIP.

Jusuf, A. H. (2005). Dasar-Dasar Akuntansi. STIE YKPN.

Laudon Kenneth C, \& Laudon, J. (2012). Management Information Systems - Managing The Digital Firm (12th ed.). Pearson Prentice Hall.

Mulyadi. (2016). Sistem Akuntansi Edisi 4. In Sistem Akuntansi Edisi 4.

Rusdianto. (2012). Pengantar Akuntansi. Erlangga.

Soemarso S.R. (2010). Akuntansi Suatu Pengantar (Cetakan Ke3). Rineka Cipta.

Sujarweni, V. W. (2015). Sistem Akuntansi. Pustaka Baru Press.

Suwardjono. (2013). Teori Akuntansi Perekayasaan Pelaporan Keuangan, Edisi Ketiga, Yogyakarta: BPFE. In 2020.

Zaki Baridwan. (2009). Sistem Akuntansi. BPFE. 